\title{
ANTIBACTERIAL ACTIVITY AND CHARACTERISATION OF SOME EGYPTIAN HONEY OF DIFFERENT FLORAL ORIGIN
}

\author{
A. G. HEGAZI ${ }^{1}$, F. M. AL GUTHAMI ${ }^{2}$, A. F. M. AL GETHAMI ${ }^{2}$, \\ E. A. FOUAD ${ }^{3} \&$ A. M. ABDOU ${ }^{3}$ \\ ${ }^{1}$ Department of Zoonotic Diseases, National Research Centre, 12622 Dokki, Giza, \\ Egypt; ${ }^{2} \mathrm{Al}$ Guthami Foundation, Saudi Arabia; ${ }^{3}$ Department of Microbiology and \\ Immunology, National Research Centre 12622 Dokki, Giza, Egypt
}

\section{Summary}

Hegazi, A. G., F. M. Al Guthami, A. F. M. Al Gethami, E. A. Fouad \& A. M. Abdou, 2021. Antibacterial activity and characterisation of some Egyptian honey of different floral origin. Bulg. J. Vet. Med., 24, No 2, 278-290.

The aim of the current study was to evaluate the antibacterial activity and to analyse the physicochemical properties of some Egyptian honey of different botanical origin in comparison with Manuka honey from New Zealand. Antibacterial activity of Egyptian honey of different floral origin was evaluated against five reference bacterial strains including both Gram-positive and Gram-negative bacteria using well diffusion method. Pollen analysis was used to confirm the floral origin of honey. Meanwhile, the physicochemical parameters including total phenolic and total flavonoid contents were measured to assess the quality of honey. Some honey types including Flowers, Aashab, Bardakosh, and Black seed honey showed significant antibacterial activity against Staphylococcus aureus (ATCC 25923) when compared with clindamycin. The same types of honey, except Black seed honey exhibited significant antibacterial activity against Citrobacter diversus (ATCC 13315). The total phenolic and total flavonoid contents ranged from $130.5 \pm 9.0$ to $175.3 \pm 11.3 \mathrm{mg}$ GAE/100 $\mathrm{g}$ honey and $22.3 \pm 1.7-30.9 \pm 2.6 \mathrm{mg} \mathrm{RE} / 100 \mathrm{~g}$ honey, respectively. The results indicated that Egyptian honey is a promising natural product that can be potentially used as an alternative to synthetic antibiotics. Authentication of honey through the investigation of its physicochemical characteristics is a very important determinant of its biological activity. Separation and investigation of the antimicrobial activity of each of the active compounds of honey will provide more information on the efficacy and the mechanism of its biological activity. Further studies are still needed to identify and standardise protocols for the use of honey either in the protection against or the treatment of microbial infections.

Key words: antibacterial activity, Egyptian honey, physicochemical parameters, total phenolic, total flavonoid

\section{INTRODUCTION}

Honey was recognised for its safe and effective use in alternative medicine since ancient times. It contains several organic and inorganic compounds exhibiting vari- 
ous biological activities including antibacterial, antiviral, antifungal, anti-inflammatory, antitumor and antioxidant activity (Hegazi \& Abd El-Hady, 2009; Hegazi, 2011; Hegazi \& AbdAllah, 2012; Hegazi et al., 2014; Khan et al., 2018). The biological effect of each honey type is a reflection of its composition which is affected by different factors including pollen composition, climate, environmental conditions, harvesting, handling, and processing (Alvarez-Suarez et al., 2014; Pasias et al., 2018). The floral source of honey, which provide nectar and pollen, is one of the natural factors which greatly affect the physicochemical characteristics of honey (Warui et al., 2019). Physicochemical properties of honey including $\mathrm{pH}$, acidity, moisture, sugars and protein content as well as sensorial characteristics including colour, texture, aroma and flavour can be used as indicators of both quality and origin of honey (Kumar et al., 2018). The therapeutic activity of honey including its antioxidant activity is mainly due to the presence of phenolic compounds such as phenolic acid and flavonoids (Cianciosi et al., 2018).

In the current study, the antibacterial activity, pollen analysis, physicochemical characteristics, total phenolic and total flavonoid contents of some Egyptian honey types were determined in comparison with Manuka honey from New Zealand.

\section{MATERIALS AND METHODS}

\section{Bacterial strains}

Five pathogenic bacterial strains including Staphylococcus aureus (ATCC 25923) representing Gram positive bacteria and Escherichia coli (ATCC 35218), Proteus vulgaris (ATCC 13315), Citrobacter diversus (ATCC 13315) and Salmonella enterica (ATCC 700931) representing Gram negative bacteria were used in this study.

\section{Honey samples}

A total of 6 fresh Egyptian honey types of different floral origin and Manuka honey were used in this study (Table 1). Five samples were collected from each type of honey. Before and during the analyses, samples were stored in glass containers, transferred to the laboratory and maintained at $4{ }^{\circ} \mathrm{C}$ until the time of the experiment. Egyptian honey samples were collected during the harvesting and flowering season period by local suppliers between April and June 2017 from six different geographical regions. Manuka honey from New Zealand was used as the standard authorised honey type .

\section{Pollen analysis}

A total of $10 \mathrm{~mL}$ of honey were mixed with $20 \mathrm{~mL}$ of distilled water. The mixture was centrifuged at $5000 \mathrm{rpm}$ for $10 \mathrm{~min}$. The supernatant was removed and $10 \mathrm{~mL}$

Table 1. List of honey types and their floral origin

\begin{tabular}{lll}
\hline & Honey name & Floral origin/place \\
\hline 1 & Sahrawy & Desert plants/ south desert near Matroh Governorate \\
2 & Zater & Thyme herb: Thymus vulgaris \\
3 & Flowers & different flowers \\
4 & Bardakosh & Origanum majorana \\
5 & Black seeds & Nigella sativa \\
6 & Aashab & wild herbs \\
7 & Manuka & Manuka tree/ New Zealand \\
\hline
\end{tabular}


of glacial acetic acid was added and the mixture was allowed to stand for $5 \mathrm{~min}$. The mixture was then centrifuged and decanted. A total of $1 \mathrm{~mL}$ of $10 \%$ potassium hydroxide was added to the sediment and boiled on a water bath at $70{ }^{\circ} \mathrm{C}$ for 5 min. The mixture was then centrifuged to remove potassium hydroxide and the sediment containing pollen was mounted in glycerin jelly on a glass slide. The slide was covered by a cover slip and the samples were observed under microscope with $400 \times$ magnification to identify the type of pollen through the comparison with the pollen source catalogues of flowers in the study area (Rosdi et al., 2016).

\section{Physicochemical analysis and sugar} composition of honey

The physicochemical analysis of honey samples was carried out to determine moisture content, hydroxymethylfurfural, diastase activity and acidity. Sugar composition including glucose and fructose concentration was also determined (Ng'ang'a et al., 2013; Manzanares et al., 2014; 2017).

\section{Determination of mineral elements}

The mineral composition including $\mathrm{Fe}$, $\mathrm{Mn}, \mathrm{Zn}, \mathrm{Cu}, \mathrm{Ca}$ and $\mathrm{Mg}$ were determined in honey samples by atomic absorption spectrometry (Silva et al., 2017).

\section{Total phenolic content (TPC)}

The total phenolic content (TPC) of honey samples was analysed by using FolinCiocalteu reagent, based on the method described by Beretta et al. (2005) with some modification (Bertoncelj et al, 2007; Chua et al., 2013). Honey solution $(0.5 \mathrm{~mL})$ was mixed with $2.5 \mathrm{~mL}$ of FolinCiocalteu reagent $(2 \mathrm{~N})$ and incubated for $5 \mathrm{~min}$. Subsequently, $2 \mathrm{~mL}$ of sodium carbonate solution $(75 \mathrm{~g} / \mathrm{L})$ was added to the honey solution and incubated for another $2 \mathrm{~h}$ at $25{ }^{\circ} \mathrm{C}$. After incubation, the absorbance of the solution was measured at $765 \mathrm{~nm}$ by using a UV-Visible spectrophotometer (Perkin-Elmer Lambda 25, Waltham, MA, USA). Gallic acid (0$1000 \mathrm{mg} / \mathrm{L}$ ) was used as a standard chemical for calibration curve preparation. The TPC was reported as a mean value of triplicate assays and expressed as milligram of gallic acid equivalent (GAE) in the gram of honey (Isla et al., 2011).

\section{Total flavonoid content (TFC)}

A total of $5 \mathrm{~mL}$ of honey solution with the concentration of $0.1 \mathrm{~g} / \mathrm{mL}$ was mixed with $5 \mathrm{~mL}$ of $2 \%$ aluminum chloride $\left(\mathrm{AlCl}_{3}\right)$. The mixture was then incubated for 10 min at $25{ }^{\circ} \mathrm{C}$. The absorbance of the formed complex was measured at $415 \mathrm{~nm}$ by using UV-Visible spectrophotometer. Rutin with the concentration of $0-100$ $\mathrm{mg} / \mathrm{L}$ was used as a standard chemical for calibration curve preparation. The TFC was reported as a mean value of triplicate assays and expressed as milligram of rutin equivalent (RE) in the gram of honey (Isla et al., 2011; Chua et al., 2013).

\section{Antibacterial activity of honey}

A suspension of each bacterial strain Staphylococcus aureus, Escherichia coli, Proteus vulgaris, Citrobacter diversus and Salmonella enterica was freshly prepared by inoculating fresh stock culture from the tested reference strain into broth tube containing $7 \mathrm{~mL}$ of Muller Hinton Broth. The inoculated tubes were incubated aerobically at $37^{\circ} \mathrm{C}$ for $24 \mathrm{~h}$. Serial dilutions were carried out for each strain and dilution matching with 0.5 McFarland scale standard was selected for the screening of antimicrobial activities. Antimicrobial susceptibility of honey was determined using well diffusion method. A 
volume of $100 \mu \mathrm{L}$ of cell culture suspension matching with $0.5 \mathrm{McF}$ arland of target strains was spread onto Muller Hinton agar plates. To investigate the antibacterial activity, $50 \mu \mathrm{L}$ of each honey sample was added in individual wells. A well containing $50 \mu \mathrm{L}$ of clindamycin $(30 \mathrm{mg} / \mathrm{mL})$ was used as positive control. The plates were left for $1 \mathrm{~h}$ at $25^{\circ} \mathrm{C}$ to allow a period of pre-incubation diffusion in order to minimise the effect of variation in time between the applications of different solutions. The plates were then incubated aerobically at $37^{\circ} \mathrm{C}$ for $24 \mathrm{~h}$ to allow bacterial growth. After incubation, the plates were observed and the zones of inhibition were measured to evaluate the antibacterial activity for each of the tested honey samples. The experiment was carried out in triplicates for statistical relevance and the mean \pm standard deviation (SD) of the results was calculated (Hegazi et al., 2014).

\section{Statistical analysis}

All assays including the antibacterial activity of honey samples were conducted in triplicates. The data (mean \pm standard deviation; $\mathrm{SD}$ ) were then subjected to statistical analysis (SPSS Ver. 21 (IBM, New York, US). Pearson's correlation coefficient test (r) was employed to determine the strength of linear relationships between the variables. Duncan Test of Post Hoc Multiple Comparisons in one-way ANOVA was applied for comparison between and within the groups. A probability value $\mathrm{P}<0.05$ was taken as significant (Steel \& Torrie, 1980).

\section{RESULTS}

A total of 6 honey types (5 samples/each honey type) were collected from different localities in Egypt. Pollen analysis of the samples indicated that not only the expected pollen type based on the known source of nectar, but also pollen from some other plants and flowers was present (Table 2). The pollen content of Sahrawy honey was of Ocimum basilicum (basil), Citrullus colocynthis (bitter-apple), Artemisia judaica and wildflowers. Meanwhile, pollen content of Zater (thyme) was of Thymus bovei, Tilia cordata, and wildflowers. Also, the pollen types found in flowers honey were of Acacia senegal, Ocimum basilicum, Artemisia judaica, and wild flowers. Bardakosh honey carried pollen of Origanum majorana and wildflowers. Black seed honey carried the pollen of Nigella sativa and wild flowers. Finally, the pollen types found in the Aashab honey were of Ocimum basilicum, Citrullus colocynthis, Artemisia judaica and wildflowers.

The results of the determination of the physicochemical properties of honey samples indicated that all samples including Manuka honey were comparable in moisture, glucose, fructose, and diastase enzyme contents, but there were some significant differences in sucrose, HMF and acidity (Table 3). Sucrose contents of all types of the Egyptian honey were significantly higher than sucrose content of Manuka honey. Sucrose contents of Sahrawy, Zater, Flowers, Bardakosh, Black seed, and Aashab honey were 4.5 \pm 1.5 , $5 \pm 1.3,4.8 \pm 2.1,4.7 \pm 2.3,4.6 \pm 3.3$, and $4.3 \pm 1.2 \mathrm{~g} / 100 \mathrm{~g}$ respectively as compared with $1 \pm 0 \mathrm{~g} / 100 \mathrm{~g}$ for Manuka honey. Zater, Sahrawy and Black seed honey types were significantly higher in their HMF content $(53 \pm 1,45 \pm 3$, and $41 \pm 4$ $\mathrm{mg} / \mathrm{kg}$ respectively) as compared with $25 \pm 1 \mathrm{mg} / \mathrm{kg}$ for Manuka honey, while the lowest HMF was that of Ashab honey $(22 \pm 3 \mathrm{mg} / \mathrm{kg})$. The acidity content of Flo- 
Antibacterial activity and characterisation of some Egyptian honey of different floral origin
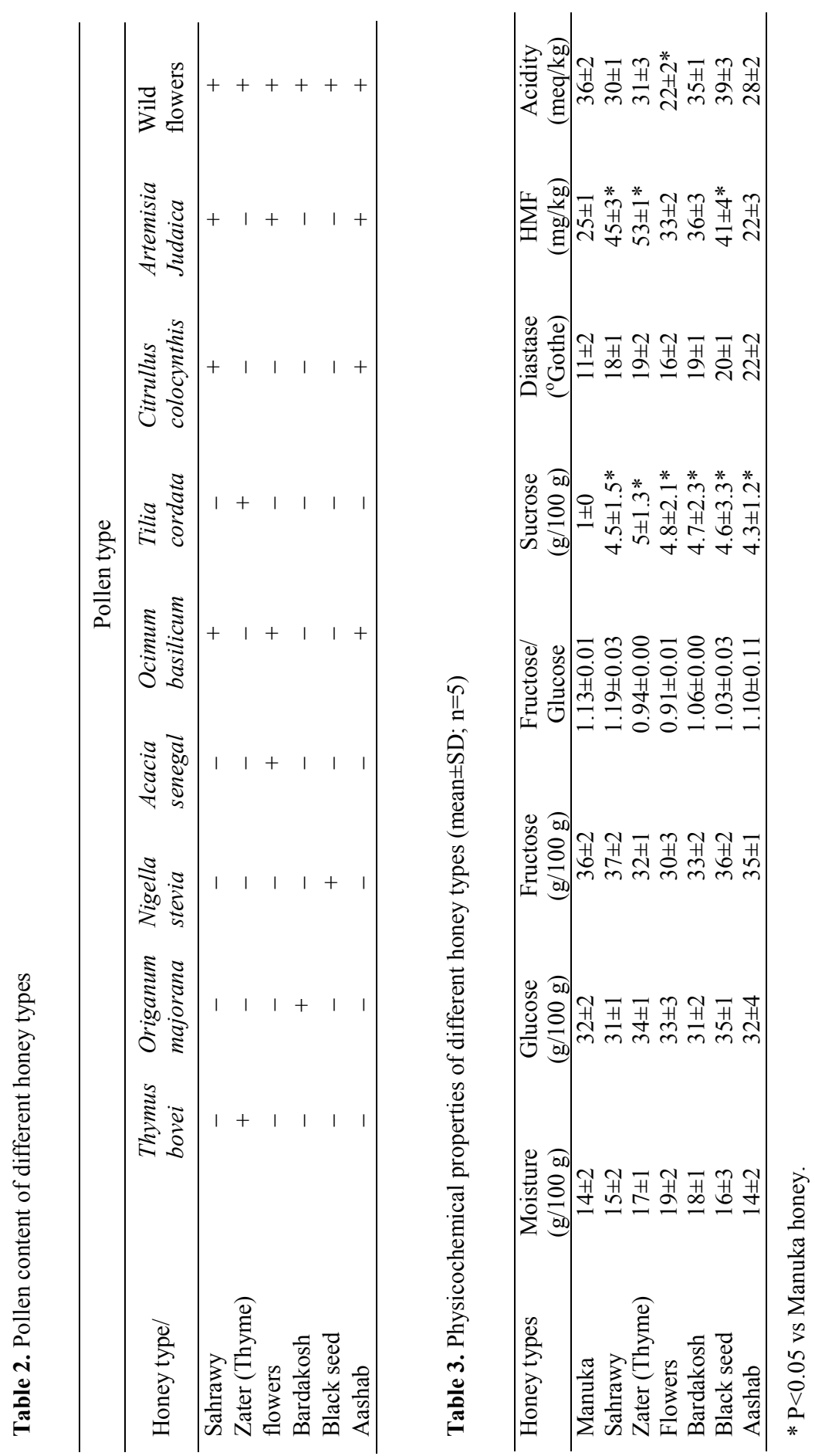
wers honey $(22 \pm 2 \mathrm{meq} / \mathrm{kg})$ was significantly lower than that of Manuka honey $(36 \pm 2 \mathrm{meq} / \mathrm{kg})$. The moisture content of the analysed honey samples ranged from $14 \pm 2-19 \pm 2 \mathrm{~g} / 100 \mathrm{~g}$ indicating comparable results for moisture contents of both Egyptian honey types and Manuka honey.

Fructose content of all honey samples was from $30 \pm 3$ to $37 \pm 2 \mathrm{~g} / 100 \mathrm{~g}$. Glucose contents of all types of honey did not show significant differences. The Egyptian Black seed honey recorded the highest glucose content: $35 \pm 1 \mathrm{~g} / 100 \mathrm{~g}$, followed by Zater - 34 $\pm 1 \mathrm{~g} / 100 \mathrm{~g}$, while the lowest content was recorded in Sahrawy and Bardakosh honey $(31 \pm 1$ and $31 \pm 2$ $\mathrm{g} / 100 \mathrm{~g}$ respectively). Fructose to glucose ratios $(\mathrm{F} / \mathrm{G})$ for all honey samples were comparable with values of $1.13 \pm 0.01$, $1.19 \pm 0.03,0.94 \pm 0.00,0.91 \pm 0.01,1.06 \pm$ $0.00,1.03 \pm 0.03$ and $1.10 \pm 0.11$ for Manuka, Sahrawy, Zater, Flowers, Bardakhosh, Nigella sativa and Aashab respectively.

The diastase numbers of the examined honey samples were comparable and ranged from $11 \pm 2$ to $22 \pm 2{ }^{\circ} \mathrm{G}$.

The mineral content of all honey samples including iron, manganese, zinc, calcium, magnesium and copper were measured in $\mathrm{mg} / \mathrm{kg}$ (Table 4). The iron contents in Black seed, Bardakosh, and Zater types of honey $(5.1 \pm 1.1,4.9 \pm 06$, and $4.8 \pm 1.0$

Table 4. Mineral elements (mean $\pm S D ; n=5)$ of different honey types $(\mathrm{mg} / \mathrm{kg})$

\begin{tabular}{lcccccc}
\hline Honey types & $\mathrm{Fe}$ & $\mathrm{Mn}$ & $\mathrm{Zn}$ & $\mathrm{Ca}$ & $\mathrm{Mg}$ & $\mathrm{Cu}$ \\
\hline Manuka & $3.7 \pm 0.3$ & $1.6 \pm 0.2$ & $1.7 \pm 0.6$ & $61.0 \pm 3.5$ & $30.1 \pm 3.1$ & $1.22 \pm 0.2$ \\
Sahrawy & $3.5 \pm 0.5$ & $1.5 \pm 0.6$ & $1.8 \pm 0.5$ & $50.8 \pm 6.4$ & $25.1 \pm 3.4$ & $1.11 \pm 0.1$ \\
Zater (Thyme) & $4.8 \pm 1.0^{*}$ & $1.7 \pm 0.2$ & $1.6 \pm 0.6$ & $56.1 \pm 5.7$ & $25.2 \pm 2.0$ & $0.91 \pm 0.2$ \\
Flowers & $3.6 \pm 0.2$ & $1.3 \pm 0.5$ & $1.4 \pm 0.4$ & $43.3 \pm 4.7$ & $26.1 \pm 4.1$ & $0.94 \pm 0.2$ \\
Bardakosh & $4.9 \pm 0.6^{*}$ & $1.6 \pm 0.3$ & $1.9 \pm 0.6$ & $59.3 \pm 7.5$ & $24.7 \pm 2.6$ & $1.16 \pm 0.4$ \\
Black seed & $5.1 \pm 1.1^{*}$ & $1.6 \pm 0.5$ & $2.1 \pm 0.5$ & $66.2 \pm 3.8$ & $24.6 \pm 3.5$ & $1.14 \pm 0.1$ \\
Aashab & $3.5 \pm 0.4$ & $1.4 \pm 0.7$ & $1.5 \pm 1.0$ & $45.9 \pm 6.6$ & $20.3 \pm 2.2$ & $0.89 \pm 0.3$ \\
\hline
\end{tabular}

* $\mathrm{P}<0.05$ vs Manuka honey.

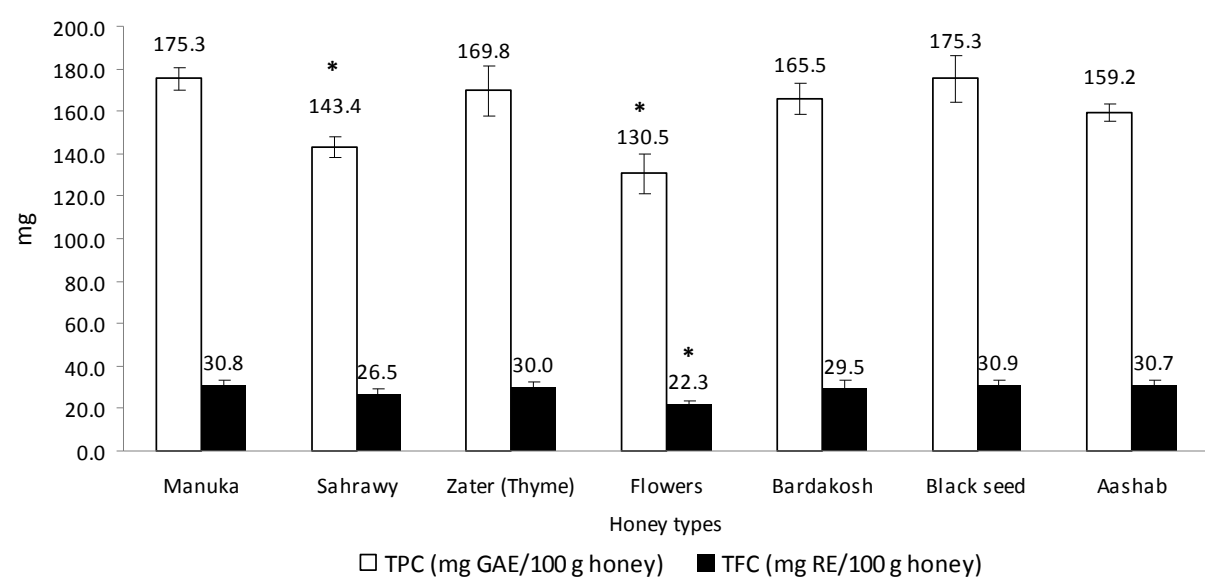

Fig. 1. Total phenolic content (TPC, mg GAE/g honey) and total flavonoid content (TFC, mg RE/g honey) of six honey types - Sahrawy, Zater, Flowers, Bardakosh, Black seed and Aashab in comparison with Manuka honey (mean of triplicate assays); ${ }^{*}$ statistically significant at the 0.05 level vs Manuka honey. 
Antibacterial activity and characterisation of some Egyptian honey of different floral origin

Table 5. Antibacterial activity of different honey types compared with clindamycin ( $m e a n \pm S D ; n=5$ )

\begin{tabular}{lccccc}
\hline & \multicolumn{5}{c}{ Bacterial strains } \\
\cline { 2 - 6 } $\begin{array}{l}\text { Honey types/ } \\
\text { antibiotic }\end{array}$ & $\begin{array}{c}\text { S. aureus } \\
\text { (ATCC }\end{array}$ & $\begin{array}{c}\text { E. coli } \\
\text { (ATCC }\end{array}$ & $\begin{array}{c}\text { P. vulgaris } \\
\text { (ATCC }\end{array}$ & $\begin{array}{c}\text { C. diversus } \\
\text { (ATCC }\end{array}$ & $\begin{array}{c}\text { S. enterica } \\
\text { (ATCC }\end{array}$ \\
& $25923)$ & $35218)$ & $13315)$ & $13315)$ & 700931 ) \\
\hline Clindamycin 30 mg & $2.2 \pm 0.3$ & $1.9 \pm 0.2$ & $1.8 \pm 0.1$ & $1.5 \pm 0.3$ & $1.6 \pm 0.1$ \\
Manuka & $2.8 \pm 0.5$ & $2.3 \pm 0.1$ & $2.0 \pm 0.4$ & $1.9 \pm 0.1$ & $1.9 \pm 0.1$ \\
Sahrawy & $2.7 \pm 0.1$ & $2.0 \pm 0.1$ & $2.4 \pm 0.2$ & $2.5 \pm 0.1$ & $2.4 \pm 0.1$ \\
Zater (Thyme) & $3.1 \pm 0.1$ & $2.0 \pm 0.2$ & $2.2 \pm 0.1$ & $2.3 \pm 0.5$ & $2.3 \pm 0.1$ \\
Flowers & $3.8 \pm 0.1^{*}$ & $2.0 \pm 0.2$ & $2.2 \pm 0.5$ & $2.8 \pm 0.1^{*}$ & $2.4 \pm 0.4$ \\
Bardakosh & $3.4 \pm 0.2^{*}$ & $2.0 \pm 0.4$ & $2.4 \pm 0.3$ & $2.5 \pm 0.1^{*}$ & $2.1 \pm 0.1$ \\
Black seed & $3.3 \pm 0.1^{*}$ & $2.2 \pm 0.2$ & $2.3 \pm 04$ & $2.4 \pm 0.2$ & $2.1 \pm 0.3$ \\
Aashab & $3.5 \pm 0.2^{*}$ & $2.1 \pm 03$ & $2.1 \pm 01$ & $2.6 \pm 03^{*}$ & $2.2 \pm 01$ \\
\hline
\end{tabular}

$* \mathrm{P}<0.05$ vs Manuka honey.

$\mathrm{mg} / \mathrm{kg}$ respectively) were significantly different when compared with the iron content of Manuka honey $(3.7 \pm 0.3$ $\mathrm{mg} / \mathrm{kg}$ ). While Manuka honey scored the highest level of magnesium (30.1 \pm 3.1 $\mathrm{mg} / \mathrm{kg})$, Black seed honey scored the highest level of calcium $(66.2 \pm 3.8 \mathrm{mg} / \mathrm{kg})$.

The total phenolic content (TPC) of tested honey samples ranged from $130.5 \pm 9.0$ to $175.3 \pm 11.3 \mathrm{mg}$ GAE/ $100 \mathrm{~g}$ honey for Flower and Black seed honey respectively. The total flavonoid content (TFC) of honey samples exhibited values within the range $22.3 \pm 1.7-30.9 \pm 2.6 \mathrm{mg}$ $\mathrm{RE} / 100 \mathrm{~g}$ honey for Flowers and Black seed honey respectively (Fig. 1). Flowers honey was significantly lower in both TPC and TFC (130.5 $\pm 9.0 \mathrm{mg}$ GAE/100 g honey and $22.3 \pm 1.7 \mathrm{mg}$ RE/100 g honey, respectively) when compared with Manuka honey $(175.3 \pm 5.4 \mathrm{mg}$ GAE/100 g honey and 30.8 $\pm 2.9 \mathrm{mg} \mathrm{RE} / 100 \mathrm{~g}$ honey, respectively). Sahrawy honey also exhibited significantly lower TPC (143.4 \pm 4.9 mg GAE/100 g honey) than Manuka honey.

The antibacterial activity of different types of honey against $S$. aureus, E. coli, $P$. vulgaris, $C$. diversus and $S$. enterica is shown in Table 5. In general all types of honey exhibited relatively higher antibacterial activity against tested strains compared to clindamycin. Both flower and Aashab honey showed significant antibacterial activity against $S$. aureus with inhibition zones of $3.8 \pm 0.1$ and $3.5 \pm 0.2 \mathrm{~cm}$ respectively, followed by Bardakosh and Black seed honey with inhibition zones of $3.4 \pm 0.2$ and $3.3 \pm 0.1 \mathrm{~cm}$ respectively compared with $2.2 \pm 0.3$ for clindamycin. Flower, Aashab, and Bardakosh honey also showed significant antibacterial activity against $C$. diversus with inhibition zones of $2.8 \pm 0.1, \quad 2.6 \pm 0.3$, and $2.5 \pm 0.1$ $\mathrm{cm}$ respectively compared with $1.5 \pm 0.3$ for clindamycin.

\section{DISCUSSION}

Honeybees produce several products including honey, propolis, royal jelly, bee venom and beeswax which contain several medicinally important compounds. Honey is considered as the most appreciated and widely used honeybee product (Cornara et al., 2017). The antibacterial activity of natural, authentic honey is well documented with the identification of novel antimicro- 
bial compounds (Ayaad et al., 2012; Fyfe et al., 2017; Hegazi et al., 2017; Hussain, 2018). Adulteration of honey either by adding cheap sugar syrup or by feeding the bees on sugar solutions is a major worldwide problem that leads to the loss of many biological properties of honey including its effective antimicrobial activity. Therefore, the selection of fresh and authentic honey based on the physicochemical characteristics is a very important step towards the potential use of specific types of honey as candidate antibacterial agents.

Around 200 compounds have been reported in honey (da Silva et al., 2016). Honey is produced through the digestive processing of nectar collected from flowers (Cornara et al., 2017). In the current study honey samples were of multifloral origin as they were rich in different pollen types indicating that nectar was collected from different plant sources. Although unifloral honey is usually more expensive and appreciated than multifloral honey (Dias et al., 2015; Di Rosa et al., 2018), the last was reported to have diverse classes of volatile compounds due to the diversity of its floral origin (Devi et al., 2018), which could be the cause of more potent biological activity and medical importance. In the current study, we used Manuka honey produced from the nectar of manuka tree as the standard honey. In spite of its monofloral origin and the multifloral origin of the Egyptian honey samples; Manuka honey was used for comparison due to its trusted source and guaranteed quality. The Ministry of Primary Industries in New Zealand approved a 5 test analysis since 5 January 2018 to prevent adulteration and to ensure the authenticity of Manuka honey (Anonymous, 2018). Furthermore, Manuka honey is considered as medical grade honey which is currently used in clinical applications (Vatansever et al., 2013).

Moisture content of honey is one of the most important parameters. Low moisture content elongates honey shelf life while high moisture levels promote the process of fermentation during storage. Moisture content of Egyptian honey samples were comparable to the moisture content of Manuka honey and within the accepted range of moisture content which, in general, should not exceed 20\% (Oroian \& Sorina, 2017; Se et al., 2019). The moisture content of the honey is affected by the temperature and relative humidity in the geographical origin during honey production by bees. Although some exceptions may apply for the moisture content of some types of honey, similar results were documented earlier for honey samples of different origin including Egyptian, Yemeni, Saudi and Kashmiri honey (El-Sohaimy et al., 2015).

Sugar content of honey is one of the parameters which are used to assess the authenticity of honey and the evaluation of its overall quality. Mixing the honey with other cheaper sugar syrups is a worldwide problem of honey adulteration (Salvador et al., 2019). Sugar analysis of honey is a good indication of whether the honeybees were fed naturally on flowers nectar or they were fed on sugar solution. When the glucose content of honey is much higher than its fructose content this indicates the use of sugar solution to feed honeybees (El-Sohaimy et al., 2015). Sugar contents of Egyptian honey samples were comparable to the sugar content of Manuka honey. The sum of glucose and fructose, which measures the content of reducing sugars in honey, was within the accepted range to prove the authenticity of honey. Fructose and glucose were the most dominant sugars in honey samples 
and the fructose to glucose ratios $(\mathrm{F} / \mathrm{G})$ indicated the natural feeding of honeybees. Meanwhile, sucrose content in all samples did not exceed $5 \%$ which is the accepted level to prove the authenticity of honey. Higher content of sucrose may indicate adulteration or artificial feeding of bees on some types of sugar syrup (Salvador et al., 2019).

Both diastase activity and hydroxymethylfurfural content are also two important parameters used to prove the authenticity and freshness of honey and as indication of adulteration. Many factors are affecting diastase activity including the age of bees, nectar collection period, the physiological period of the colony and the quantity of nectar and its sugar content. The maximum level for the 5-HMF content in honey was established by the Codex Alimentarius of the World Health Organization and the European Union to be $40 \mathrm{mg} / \mathrm{kg}$ but in case of honey from countries with tropical ambient temperatures the HMF content should not exceed $80 \mathrm{mg} / \mathrm{kg}$ (Anonymous, 2001; Pasias et al. 2017). In our study all samples were within the accepted range for diastase number and HMF content as an indication of the authenticity and freshness of all samples which was achieved by collecting honey samples during the flowering season, preventing their exposure to heat and shortening the storage time before the experiment.

Acidity of all honey samples was found to be within the accepted range. The presence of organic acids, particularly the gluconic acid, was found to affect honey flavour, texture, shelf life and stability (Warui et al., 2019).

The source of honey, the geographical origin and the type of both plants and soil are the most important parameters to determine the mineral composition of honey.
The mineral composition of honey is an important factor to determine the nutritional value of honey and it also affects the colour and the flavour of honey (Kadri et al., 2017; Silva et al., 2017). The similarity of mineral contents between different types of Egyptian honey could be due to the similarity in soil and climate as almost all honey types were collected from areas around The Nile River and Delta with almost the same soil contents and the same climate.

The total phenolic content of different types of honey in our study were $130.5 \pm 9.0$ to $175.3 \pm 11.3 \mathrm{mg} \mathrm{GAE} / 100 \mathrm{~g}$ honey which is higher than the results found in honey, especially monofloral honey, from other countries including India (47-98 mg GAE/100 g honey) (Saxena et al., 2010), Argentina (18.730 $107.213 \mathrm{mg}$ GAE/100 g honey) (Isla et al., 2011), Burkina Faso (32.59-114.75 mg GAE/100 g honey) (Meda et al., 2005), Portuguese (30.87 to $87.27 \mathrm{mg}$ GAE/100 g) (Gonçalves et al., 2018), and Romania (2-125 mg GAE/100 g honey) (Al et al., 2009).

Variable levels of total phenolic contents were reported in different honey types. This variability was associated with the floral origin of honey and multifloral honey was found to have higher phenolic contents than monoforal honey. Multifloral honey was also higher in its flavonoid contents than monolfloal honey. The phenolic compounds, especially flavonoids, of honey are a major determinant of its antioxidant, antimicrobial, antiviral, antifungal, and anti-inflammatory activity. It is worth mentioning that, the quality of polyphenols is more important than their quantity (Pasupuleti et al., 2007; Isla et al., 2011).

In our study, most types of honey were comparable in their antibacterial activity 
which may be attributed to the narrow ranges of their total phenolic contents, total flavonoid contents, and sugar contents. Although there was a positive correlation between TPC and antibacterial activity of both Bardakosh and Black seed honey, there was a negative correlation between TPC and antibacterial activity of Flowers honey. A significant correlation between TPC and antibacterial activity against $P$. aeruginosa was reported earlier which was suggested to be due to inhibition in the virulence factors of the pathogen (Stagos et al., 2018). On the other hand a week correlation was reported between the antioxidant activity and antimicrobial activity of some commercial honeys from the Polish market (Makarewicz et al., 2017). The antimicrobial activity of honey resulted not only from the phenolic compounds, but also from the low $\mathrm{pH}$ and high osmolarity along with the activity of hydrogen peroxide produced by glucose oxidase enzyme in bees (Meo et al., 2017). The antimicrobial activity of honey may be attributed also to the presence of lysozyme, methyloglyoxal, and bee peptides as well as its high sugar contents (Israili, 2014).

\section{CONCLUSIONS}

Egyptian honey is a promising natural product that can be potentially used as an alternative to synthetic antibiotics. Authentication of honey through the investigation of its physicochemical characteristics is a very important determinant of its biological activity. Separation and investigation of the antimicrobial activity of each of the active compounds of honey well provide more information on the efficacy and the mechanism of their biological activity. Further studies are also needed to identify and standardise proto- cols for the use of honey either in the protection against or the treatment of microbial infections.

\section{ACKNOWLEDGEMENTS}

The authors are grateful for the financial support by the National Research Center of Egypt under registration number $12 / 5 / 1$ and $\mathrm{Al}$ Guthami Foundation, Saudi Arabia.

\section{REFERENCES}

Al, M. L., D. Daniel, A. Moise, O. Bobis, L. Laslo \& S. Bogdanov, 2009. Physicochemical and bioactive properties of different floral origin honeys from Romania. Food Chemistry, 112, 863-867.

Alvarez-Suarez, J. M., M. Gasparrini, T. Y. Forbes-Hernandez, L. Mazzoni \& F. Giampieri, 2014. The Composition and biological activity of honey: A focus on Manuka honey. Foods, 3, 420-432.

Anonymous, 2001. Alinorm01/25, 2001. CodexAlimentarius. http://www.google.bg/ url? sa $=\mathrm{t} \& \mathrm{rct}=\mathrm{j} \& \mathrm{q}=\& \mathrm{esrc}=\mathrm{s} \&$ source $=$ web $\& \mathrm{~cd}=1 \& \mathrm{cad}=$ rja \&uact $=8 \&$ ved $=2$ ahUKEwj uzbr47KfkAhWKVRUIHXVqA2gQFjAA egQIAhAC\&url=http $\% 3 \mathrm{~A} \% 2 \mathrm{~F} \% 2 \mathrm{Fwww}$. fao.org\% $\%$ Finput $\% 2$ Fdownload $\% 2$ Freport \%2F277\%2FA101_25e.pdf\&usg=AOvVa w0I7rbQWdUM8g7sAVEWy9M_(29 August 2019 date last accessed).

Anonymous, 2018. Ministry for Primary Industries. Apiculture Monitoring Programme. https://www.mpi.govt.nz/dmsdocument/34329 (29 August 2019 date last accessed).

Ayaad, T. H., G. H. Shaker \& A. M. Almuhnaa, 2012. Isolation of antimicrobial peptides from Apis florae and Apis carnica in Saudi Arabia and investigation of the antimicrobial properties of natural honey samples. Journal of King Saud University - Science, 24, 193-200.

Beretta, G., P. Granata, M. Ferrero, M. Orioli \& R. M. Facino, 2005. Standardization of 
antioxidant properties of honey by a combination of spectrophotometric/fluorimetric assays and chemometrics. Analytica Chimica Acta, 533, 185-191.

Bertoncelj, J., U. k. Doberšek, M. Jamnik \& T. Golob, 2007. Evaluation of the phenolic content, antioxidant activity and colour of Slovenian honey. Food Chemistry, 105, 822-828.

Chua, L. S., N. L. Rahaman, N. A. Adnan \& T. T. Eddie Tan, 2013. Antioxidant activity of three honey samples in relation with their biochemical components. Journal of Analytical Methods in Chemistry, 2013, 313798.

Cianciosi, D., T. Y. Forbes-Hernandez, S. Afrin, M. Gasparrini, P. Reboredo-Rodriguez, P. P. Manna, J. Zhang, L. Bravo Lamas, S. Martinez Florez, P. Agudo Toyos, J. L. Quiles, F. Giampieri \& M. Battino, 2018. Phenolic compounds in honey and their associated health benefits: A review. Molecules, 23.

Cornara, L., M. Biagi, J. Xiao \& B. Burlando, 2017. Therapeutic properties of bioactive compounds from different honeybee products. Fronters in Pharmacology, 8, 412.

da Silva, P. M., C. Gauche, L. V. Gonzaga, A. C. Costa \& R. Fett, 2016. Honey: Chemical composition, stability and authenticity. Food Chemistry, 196, 309-323.

Devi, A., J. Jangir \& A. A. K, 2018. Chemical characterization complemented with chemometrics for the botanical origin identification of unifloral and multifloral honeys from India. Food Research International, 107, 216-226.

Di Rosa, A. R., A. M. F. Marino, F. Leone, G. G. Corpina, R. P. Giunta \& V. Chiofalo, 2018. Characterization of Sicilian honeys pollen profiles using a commercial etongue and melissopalynological analysis for rapid screening: A pilot study. Sensors (Basel), 18.

Dias, L. G., A. C. Veloso, M. E. Sousa, L. Estevinho, A. A. Machado \& A. M. Peres, 2015. A novel approach for honey pollen profile assessment using an electronic tongue and chemometric tools. Analytica Chimica Acta, 900, 36-45.

El-Sohaimy, S. A., S. H. D. Masry \& M. G. Shehata, 2015. Physicochemical characteristics of honey from different origins. $A n$ nals of Agricultural Science, 60, 279-287.

Fyfe, L., P. Okoro, E. Paterson, S. Coyle \& G. J. McDougall, 2017. Compositional analysis of Scottish honeys with antimicrobial activity against antibiotic-resistant bacteria reveals novel antimicrobial components. LWT - Food Science and Technology, 79 , 52-59.

Gonçalves, J., I. Ribeiro, J. Marçalo, P. Rijo, C. Faustino \& L. Pinheiro, 2018. Physicochemical, antioxidant and antimicrobial properties of selected Portuguese commercial monofloral honeys. Journal of Food and Nutrition Research, 6, 645-654.

Hegazi, A., S. I. A. El-Moez, A. M. Abdou \& F. A. Allah, 2014. Synergistic antibacterial activity of Egyptian honey and common antibiotics against Clostridium reference strains. International Journal of Current Microbiology and Applied Sciences, 3, 312-325.

Hegazi, A. G., 2011. Antimicrobial activity of different Egyptian honeys as comparsion of Saudi Arabia honey. Research Journal of Microbiology, 6, 488-495.

Hegazi, A. G. \& F. K. Abd El-Hady, 2009. Influence of honey on the suppression of human low density lipoprotein (LDL) peroxidation (In vitro). Evidence-Based Complementary and Alternative Medicine, 6, 113-121.

Hegazi, A. G., S. I. Abd El-Moez, M. A. Abdou \& F. A. Allah, 2014. Antibacterial Activity of some types of monofloral honey against Clostridium acetobutylicum and Clostridium perfringens. International Journal of Current Microbiology and Applied Sciences, 3, 552-565.

Hegazi, A. G. \& F. M. AbdAllah, 2012. antimicrobial activity of different Saudi Arabia honeys. Global Veterinaria, 9, 53-59. 
Hegazi, A. G., F. M. Guthami, A. F. Gethami, F. M. Allah, A. A. Saleh \& E. A. Fouad, 2017. Potential antibacterial activity of some Saudi Arabia honey. Veterinary World, 10, 233-237.

Hussain, M. B., 2018. Role of honey in topical and systemic bacterial infections. Journal of Alternative and Complement Medicine, 24, 15-24.

Isla, M. I., A. Craig, R. Ordoñez, C. Zampini, J. Sayago, E. Bedascarrasbure, A. Alvarez, V. Salomón \& L. Maldonado, 2011. Physico chemical and bioactive properties of honeys from Northwestern Argentina. LWT - Food Science and Technology, 44, 1922-1930.

Israili, Z. H., 2014. Antimicrobial properties of honey. American Journal of Therapeutics, 21, 304-323.

Kadri, S. M., R. Zaluski \& R. O. Orsi, 2017. Nutritional and mineral contents of honey extracted by centrifugation and pressed processes. Food Chemistry, 218, 237-241.

Khan, S. U., S. I. Anjum, K. Rahman, M. J. Ansari, W. U. Khan, S. Kamal, B. Khattak, A. Muhammad \& H. U. Khan, 2018. Honey: Single food stuff comprises many drugs. Saudi Journal of Biological Sciences, 25, 320-325.

Kumar, A., J. P. S. Gill, J. S. Bedi, M. Manav, M. J. Ansari \& G. S. Walia, 2018. Sensorial and physicochemical analysis of Indian honeys for assessment of quality and floral origins. Food Research Internaitonal, 108, 571-583.

Makarewicz, M., Kowalski S., Lukasiewicz M. \& M. Małysa-Paśko, 2017. Antimicrobial and antioxidant properties of some commercial honeys available on the Polish market. Czech Journal of Food Sciences, 35, 401-406.

Manzanares, A. B., Z. H. García, B. R. Galdón, E. R. Rodríguez \& C. D. Romero, 2014. Physicochemical characteristics of minor monofloral honeys from Tenerife, Spain. LWT - Food Science and Technology, 55, 572-578.
Manzanares, A. B., Z. Hernandez Garcia, B. Rodriguez Galdon, E. M. RodriguezRodriguez \& C. Diaz Romero, 2017. Physicochemical characteristics and pollen spectrum of monofloral honeys from Tenerife, Spain. Food Chemistry, 228, 441-446.

Meda, A., C. E. Lamien, M. Romito, J. Millogo \& O. G. Nacoulma, 2005. Determination of the total phenolic, flavonoid and proline contents in Burkina Fasan honey, as well as their radical scavenging activity. Food Chemistry, 91 571-577.

Meo, S. A., S. A. Al-Asiri, A. L. Mahesar \& M. J. Ansari, 2017. Role of honey in modern medicine. Saudi Journal of Biological Sciences, 24, 975-978.

Ng'ang'a, F., A. Onditi, A. Gachanja \& E. Ngumba, 2013. Physicochemical analysis of honey in the Kenyan retail market. Food Science and Quality Management, 12 , 30-36.

Oroian, M. \& R. Sorina, 2017. Honey authentication based on physicochemical parameters and phenolic compounds. Computers and Electronics in Agriculture 138, 148 156.

Pasias, I. N., I. K. Kiriakou, A. Kaitatzis, A. E. Koutelidakis \& C. Proestos, 2018. Effect of late harvest and floral origin on honey antibacterial properties and quality parameters. Food Chemistry, 242, 513-518.

Pasias, I. N., I. K. Kiriakou \& C. Proestos, 2017. HMF and diastase activity in honeys: A fully validated approach and a chemometric analysis for identification of honey freshness and adulteration. Food Chemistry, 229, 425-431.

Pasupuleti, V. R., L. Sammugam, N. Ramesh \& S. H. Gan, 2007. Honey, propolis, and royal jelly: A comprehensive review of their biological actions and health benefits. Oxidative Medicine and Cellular Longevity, 2017, 1259510.

Rosdi, I. N., K. Selvaraju, P. Vikram, K. Thevan \& M. Arifullah, 2016. Melissopalynological analysis of forest honey from North Malaysia. Journal of Tropical Re- 
sources and Sustainable Science, $\mathbf{4}$, 128-132.

Salvador, L., M. Guijarro, D. Rubio, B. Aucatoma, T. Guillen, P. Vargas Jentzsch, V. Ciobota, L. Stolker, S. Ulic, L. Vasquez, P. Garrido, J. Bravo \& L. Ramos Guerrero, 2019. Exploratory monitoring of the quality and authenticity of commercial honey in Ecuador. Foods, 8.

Saxena, S., S. Gautam \& A. Sharma, 2010. Physical, biochemical and antioxidant properties of some Indian honeys. Food Chemistry, 118, 391-397.

Se, K. W., R. A. Wahab, S. N. S. Yaacob \& S. K. Ghoshal, 2019. Detection techniques for adulterants in honey: Challenges and recent trends. Journal of Food Composition and Analysis, https://doi.org/10.1016/ j.jfca.2019.04.001.

Silva, L. R., A. Sousa \& M. Taveira, 2017. Characterization of Portuguese honey from Castelo Branco region according to their pollen spectrum, physicochemical characteristics and mineral contents. Journal of Food Science and Technology, 54, 2551-2561.

Stagos, D., N. Soulitsiotis, C. Tsadila, S. Papaeconomou, C. Arvanitis, A. Ntontos, F. Karkanta, S. Adamou-Androulaki, K. Petrotos, D. A. Spandidos, D. Kouretas \& D. Mossialos, 2018. Antibacterial and antioxidant activity of different types of honey derived from Mount Olympus in Greece. International Journal of Molecular Medicine, 42, 726-734.
Steel, R. G. D. \& J. H. Torrie, 1980. Principles and Procedures of Statistics, McGraw Hill Book Company, New York.

Vatansever, F., W. C. de Melo, P. Avci, D. Vecchio, M. Sadasivam, A. Gupta, R. Chandran, M. Karimi, N. A. Parizotto, R. Yin, G. P. Tegos \& M. R. Hamblin, 2013. Antimicrobial strategies centered around reactive oxygen species--bactericidal antibiotics, photodynamic therapy, and beyond. FEMS Microbiology Reviews, 37, 955-989.

Warui, M. W., L. Hansted, M. Gikungu, J. Mburu, G. Kironchi \& A. S. Bosselmann, 2019. Characterization of Kenyan honeys based on their physicochemical properties, botanical and geographical origin. International Journal of Food Science, 2019, 2932509.

Paper received 30.04.2019; accepted for publication 25.08.2019

\section{Correspondence:}

Amr Mohamed Khair Hussein Abdou Department of Microbiology and Immunology, National Research Centre 12622 Dokki, Giza, Egypt,

e-mail: amrkheir@yahoo.com 